\title{
Trophic niches of thirteen damselfishes (Pomacentridae) at the Grand Récif of Toliara, Madagascar
}

\author{
Bruno Frédérich · Grégory Fabri · Gilles Lepoint • \\ Pierre Vandewalle $\cdot$ Eric Parmentier
}

Received: 19 November 2007/Revised: 15 March 2008/Accepted: 18 March 2008/Published online: 16 April 2008

(C) The Ichthyological Society of Japan 2008

\begin{abstract}
The damselfishes, with more than 340 species, constitute one of the most important families that live in the coral reef environment. Most of our knowledge of reef-fish ecology is based on this family, but their trophic ecology is poorly understood. The aim of the present study was to determine the trophic niches of 13 sympatric species of damselfishes by combining stable isotope $\left(\delta^{15} \mathrm{~N}\right.$ and $\left.\delta^{13} \mathrm{C}\right)$ and stomach content analyses. Isotopic signatures reveal three main groups according to their foraging strategies: pelagic feeders (Abudefduf sexfasciatus, A. sparoides, A. vaigiensis, Chromis ternatensis, C. dimidiata, Dascyllus trimaculatus and Pomacentrus caeruleus), benthic feeders (Chrysiptera unimaculata, Plectroglyphidodon lacrymatus and Amphiprion akallopisos) and an intermediate group (D. aruanus, $P$. baenschi and P. trilineatus). Stomach contents reveal that planktonic copepods and filamentous algae mainly represent the diets of pelagic feeders and benthic feeders, respectively. The intermediate position of the third group resulted from a partitioning of small planktonic prey, small vagile invertebrates and filamentous algae. In this last feeding group, the presence of a wide range of $\delta^{13} \mathrm{C}$ values in $P$. trilineatus suggests a larger trophic niche width, related to diet-switching over time. Some general considerations about the feeding habits of damselfishes reveal that their choice of habitat on the reef and their behavior appear to be good predictors of diet in this group. Benthic (algae and/or small invertebrates)
\end{abstract}

B. Frédérich $(\bowtie) \cdot$ G. Fabri $\cdot$ P. Vandewalle $\cdot$ E. Parmentier Laboratoire de Morphologie fonctionnelle et évolutive, Institut de Chimie (B6c), Université de Liège, 4000 Liège, Belgium e-mail: bruno.frederich@ulg.ac.be

G. Lepoint

MARE, Laboratoire d'Océanologie, Institut de Chimie (B6c), Université de Liège, 4000 Liège, Belgium feeders appear to be solitary and defend a small territory on the bottom; zooplankton feeders remain in groups just above the reef, in the water column.

Keywords Feeding habits - Pomacentrids .

Stable isotopes $\cdot$ Stomach contents

\section{Introduction}

Coral reefs have an extraordinary diversity of fishes, and a central goal of reef community ecology is to understand the mechanisms allowing the coexistence of so many species. The partitioning of resources (e.g., food and habitat) may be viewed as one of the key factors in the diversifying process, which promotes the coexistence of closely related and ecologically equivalent species (Colwell and Fuentes 1975). The trophic niche, defined as the place of an organism in the environment in relation to its food (Silvertown 2004), is probably one of the main axes of diversification in vertebrates (Streelman and Danley 2003). The trophic ecology of reef fishes has been broadly studied. For instance, extensive evidence of trophic adaptations and wide diversity in diet were highlighted in Labridae (Wainwright 1988; Wainwright et al. 2004) and Chaetodontidae (Motta 1988; Ferry-Graham et al. 2001; Pratchett 2005).

The damselfishes (Pomacentridae) include more than 340 species that live mainly in coral reef environments (Allen 1991; Nelson 2006). Pomacentrids are perhaps the most conspicuous inhabitants of coral reefs (Allen 1991). Their abundance has led to a legitimate focus on damselfishes in reef ecological studies; most of our knowledge of reef-fish ecology is based on this family. This is particularly true for habitat use (Waldner and Robertson 1980), larvae (Wellington and Victor 1989), settlement (Leis and 
Carson-Ewart 2002) and recruitment (Lecchini and Galzin 2005). Diverse topics on coral reef ecology related to the diet of some damselfishes have been investigated. For instance, the effects of herbivorous damselfishes on benthic communities are increasingly being studied (Hata and Kato 2002; Gobler et al. 2006; Ceccarelli 2007). Damselfishes have also served as a model fish for the study of planktivory. For example, the impacts of ecological factors like rank within social groups (Coates 1980), zooplankton dynamics (Noda et al. 1992) and current speeds (Mann and Sancho 2007) on the feeding behavior of planktivorous species were illustrated in damselfishes. However, very few works focus on all of the various trophic niches present in the family Pomacentridae. Currently, only two studies are entirely devoted to comparative feeding habits in several species of damselfishes: one at Alligator Reef, Florida Keys (Emery 1973) and another in Taiwan (Kuo and Shao 1991). In general, three main feeding guilds are considered (Allen 1991): herbivorous, planktivorous and omnivorous.

In trophic niche analysis, two main approaches are usually used: stomach content analysis and the use of stable isotope ratios. The combination of these approaches in the same study has the advantage of compensating for the inaccuracy of each method. Stomach content data are a snapshot that reflect the most recent meal and may not be representative of the overall diet. The use of stable isotope ratios of carbon $\left({ }^{13} \mathrm{C} /{ }^{12} \mathrm{C}\right)$ and nitrogen $\left({ }^{15} \mathrm{~N} /{ }^{14} \mathrm{~N}\right)$ provides complementary data in the analysis of gut contents (e.g., Cocheret de la Morinière et al. 2003; Parmentier and Das 2004). Stable isotope analysis has emerged as a powerful tool for tracing dietary sources, as the isotope ratios of a consumer are related to those of its food (Peterson and Fry 1987). This method provides an integrated measure of the dietary components over a much longer period of time than gut content analysis. Although stable isotope analysis does not provide a detailed picture of dietary preferences, it gives an average estimate of an organism's preferred diet that is much less subject to temporal bias (Pinnegar and Polunin 1999). Moreover, stable isotope analysis was recently revealed to be a powerful tool for assessing the trophic niche widths of species (Bearhop et al. 2004).

The purpose of the present study is to determine the trophic niches of 13 sympatric species of damselfishes (Table 1) through an approach combining stable isotopes $\left(\delta^{15} \mathrm{~N}\right.$ and $\left.\delta^{13} \mathrm{C}\right)$ and stomach contents. This framework will permit an informed discussion about the diversity of their feeding habits.

\section{Materials and methods}

The 13 species were collected on the "Grand Récif" of Toliara (SW Madagascar, Mozambique Channel) $\left(23.36^{\circ} \mathrm{S}\right.$,
Table 1 Species studied in this work

\begin{tabular}{llrll}
\hline Species & Abbreviations & $n$ & $n_{0}$ & SL (mm) \\
\hline Abudefduf sexfasciatus & A. sex & 11 & 2 & $83-99$ \\
Abudefduf sparoides & A. spa & 13 & 1 & $80-89$ \\
Abudefduf vaigiensis & A. vai & 9 & 3 & $93-127$ \\
Amphiprion akallopisos & Am. aka & 10 & 2 & $34-80$ \\
Chromis dimidiata & C. dim & 12 & 1 & $33-53$ \\
Chromis ternatensis & C. ter & 5 & 0 & $63-82$ \\
Chrysiptera unimaculata & Ch.uni & 15 & 0 & $53-75$ \\
Dascyllus aruanus & D. aru & 11 & 0 & $28-50$ \\
Dascyllus trimaculatus & D. tri & 13 & 0 & $37-79$ \\
Plectroglyphidodon lacrymatus & Pl. lac & 10 & 0 & $44-76$ \\
Pomacentrus baenschi & P. bae & 4 & 0 & $53-77$ \\
Pomacentrus caeruleus & P. cae & 11 & 0 & $44-67$ \\
Pomacentrus trilineatus & P. tri & 10 & 1 & $50-66$ \\
\hline
\end{tabular}

$n$ Number of specimens, $n_{0}$ number of specimens in which stomach is empty, $S L$ standard length

43.66 ${ }^{\circ}$ ) in November 2005. All specimens (Table 1) were collected on the inner reef at depths of between 2 and $15 \mathrm{~m}$ after being anesthetized by rotenon or by a solution of quinaldin. As all damselfishes exhibit diurnal feeding activity (Emery 1973), all fishes were captured in the morning (between 9 and 11 a.m.). After their capture, the fishes were brought to the surface and killed as quickly as possible by overdose immersion in MS-222. They were then placed on ice.

Each fish was weighed and its standard length (SL) was measured to the nearest millimeter. Samples $\left( \pm 2 \mathrm{~cm}^{3}\right)$ of lateral muscle tissue of each fish were used for stable isotope analysis. The entire digestive tract was removed and conserved in $70 \%$ alcohol for stomach content analysis. All fish samples showed little variation in size except in Amphiprion akallopisos, Abudefduf vaigensis, Dascyllus trimaculatus and Plectroglyphidodon lacrymatus.

Different primary food sources (plankton, benthic invertebrates and algae) were taken from the fish collection site. Suspended organic matter was obtained by filtering 51 per sample of seawater from the collection site on GF/C Whatman filters, after pre-filtering through a $250 \mu \mathrm{m}$ sieve. Meso-zooplankton was trapped using a net with a mesh of $250 \mu \mathrm{m}$, towed on the reef at a depth of $2 \mathrm{~m}$. Erect macroalgae (three species of chlorophytes, one rhodophyte and three phaeophytes) colonizing the reef and turf algae from dead coral areas, where some studied damselfishes lived, were taken. Benthic small invertebrates (such as isopods, amphipods, harpacticoid copepods, annelids) were collected from the reef during the night using light traps attached to the substratum above the bottom $(50 \mathrm{~cm})$. These traps consisted of plastic bottles (1.5 l) containing glowsticks, which were alight for $8-12 \mathrm{~h}$. 
Stomach content analysis. Stomachs were opened and all dietary constituents were identified using a Wild M10 binocular microscope or a polarizing microscope (DM 1000, Leica, Solms, Germany). In an ecomorphological context, the preys were separated into six categories reflecting the imposed functional constraints (Barel 1983): phytoplankton, benthic algae, sessile invertebrates, vagile invertebrates, zooplankton and detritus. The stomach contents were expressed by numerical methods (Hyslop 1980): the number of items in each food category was recorded for each stomach, and the total was expressed as a percentage.

The variation in diet with size was also investigated in Amphiprion akallopisos, Abudefduf vaigensis, Dascyllus trimaculatus and Plectroglyphidodon lacrymatus.

Stable isotope analysis. Samples of lateral muscle tissue and potential food sources were dehydrated for $24 \mathrm{~h}$ at $50^{\circ} \mathrm{C}$ before being ground into a homogeneous powder. After grinding, samples containing carbonates (macroalgae, zoobenthos) were placed for $24 \mathrm{~h}$ under a glass bell with fuming $\mathrm{HCl}$ (37\%) (Merck, Darmstadt, Germany, for analysis quality) in order to eliminate calcareous material. Lipids were not removed from all samples. Seawater samples were filtered through precombusted glass filters (Whatman $\mathrm{GF} / \mathrm{F}$ ) (at $450^{\circ} \mathrm{C}$, for $4 \mathrm{~h}$ ) for the isotopic analysis of particulate organic matter (POM). Carbon and nitrogen gas were analyzed on a V.G. Optima (Micromass, Beverly, MA, USA) IR-MS coupled to an N-C-S elemental analyzer (Carlo Erba, Milan, Italy). Routine measurements were precise to within $0.3 \%$ o for both $\delta^{13} \mathrm{C}$ and $\delta^{15} \mathrm{~N}$. Stable isotope ratios were expressed in $\delta$ notation according to the following:

$\delta X=\left[\left(R_{\text {sample }} / R_{\text {standard }}\right)-1\right] \times 1,000$

where $X$ is ${ }^{13} \mathrm{C}$ or ${ }^{15} \mathrm{~N}$ and $R$ is the corresponding ratio ${ }^{13} \mathrm{C} /{ }^{12} \mathrm{C}$ or ${ }^{15} \mathrm{~N} /{ }^{14} \mathrm{~N}$ for samples or standards. Carbon and nitrogen ratios are expressed relative to the vPDB (Vienna Peedee Belemnite) standard and to the atmospheric nitrogen standard, respectively. Reference materials were IAEA-N $1 \quad\left(\delta^{15} \mathrm{~N}=+0.4 \pm 0.2 \%\right) \quad$ and IAEA CH-6 (sucrose) $\left(\delta^{13} \mathrm{C}=-10.4 \pm 0.2 \%\right.$ ).

Statistical analyses. The Kolmogorov-Smirnov test was used to test the normality of the data. One-way ANOVA were used to compare isotope ratios between the different species. These analyses were computed using STATISTICA, Version 7.1 (Statsoft 2005). The computer package PRIMER (Plymouth Routines in Multivariate Ecological Research Ltd., UK, Version 5.2.9) was used to generate hierarchical clustering based on applying Euclidian distances to isotope ratios. Stomach content data were also analyzed in PRIMER using the following techniques. Hierarchical clustering was performed based on applying a Bray-Curtis similarity coefficient to percentage composition data. The nonparametric ANOSIM test (analysis of similarities) was then used to statistically test the interspecific differences in stomach contents. Finally, in order to characterize the trophic niche of each species, PRIMER was used to perform a hierarchical clustering, based on applying the Bray-Curtis similarity coefficient to all data from the two approaches.

\section{Results}

Stomach content analysis. The stomachs of 10 individuals from 134 examined specimens of the 13 species were found to be empty (Table 1). One specimen of Abudefduf vaigiensis and one of Chromis ternatensis had stomachs filled with a great number of demersal fish eggs. This finding is informative about feeding opportunism, but these two specimens were not included for calculating the mean diet composition. Relatively low variations are observed in the stomach contents of each species (standard deviations vary from 0 to $15 \%$ of the total content according to the categories of prey).

There were significant differences in the gut contents of the 13 species, as shown in Fig. 1 (ANOSIM global test statistic $R=0.565, P<0.001)$. However, pairwise comparisons revealed that some species show nonsignificant differences in diet (pairwise $R<0.5$, Table 2). According to these results, the 13 species can be grouped into three clusters (Fig. 1, Table 2). The three species of Abudefduf and $C$. ternatensis form a first cluster where zooplankton

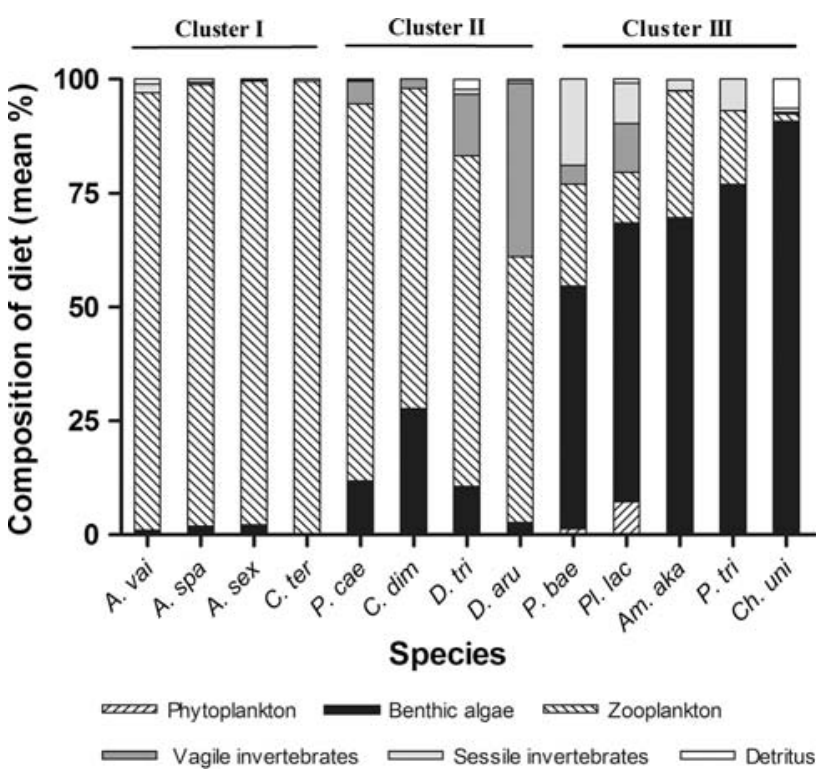

Fig. 1 Summarized dietary compositions of the 13 pomacentrid species. For abbreviations of the species, see Table 1. The six prey categories (phytoplankton, benthic algae, sessile invertebrates, vagile invertebrates, zooplankton and detritus) are represented by different color patterns 
Table 2 Pairwise comparisons of stomach contents (ANOSIM)

\begin{tabular}{|c|c|c|c|c|c|c|c|c|c|c|c|c|}
\hline & A. sex & A. spa & A. vai & Am. aka & C. dim & C. ter & Ch.uni & D. aru & D. tri & Pl. lac & P. bae & P. cae \\
\hline A. spa & - & & & & & & & & & & & \\
\hline A. vai & - & - & & & & & & & & & & \\
\hline Am. aka & $* *$ & $* *$ & $* *$ & & & & & & & & & \\
\hline C. dim & - & $*$ & - & $*$ & & & & & & & & \\
\hline C. ter & - & - & - & $* *$ & - & & & & & & & \\
\hline Ch.uni & $* *$ & $* *$ & $* *$ & - & $* *$ & $* *$ & & & & & & \\
\hline D. aru & $*$ & $* *$ & $*$ & $* *$ & * & $*$ & $* *$ & & & & & \\
\hline D. $t r i$ & - & - & - & $*$ & - & - & $* *$ & - & & & & \\
\hline Pl. lac & $* *$ & $* *$ & $* *$ & - & $*$ & $*$ & - & $*$ & $*$ & & & \\
\hline P. bae & $* *$ & $* *$ & $* *$ & - & * & $* *$ & $*$ & $* *$ & $*$ & - & & \\
\hline P. cae & - & - & - & $*$ & - & - & $* *$ & - & - & $*$ & $* *$ & \\
\hline P. tri & $* *$ & $* *$ & $* *$ & - & $*$ & $* *$ & - & $* *$ & $* *$ & - & - & $* *$ \\
\hline
\end{tabular}

For abbreviations of the species, see Table 1

** Highly significant differences between species $(R>0.75), *$ overlapping but clearly different $(R \geq 0.50)$

- No differences $(R<0.50)$

accounts for $>95 \%$ of items in the stomach contents. In these species, the prey were essentially pelagic copepods but, to a lesser extent, chaetognaths were also found in almost all of the stomachs of A. sexfasciatus and $A$. sparoides (7 and 10 specimens, respectively). The second group of species is composed of Pomacentrus caeruleus, Chromis dimidiata and both Dascyllus species. Their stomach contents reveal that they feed mainly on zooplankton, mainly consisting of planktonic copepods (58\% in Dascyllus aruanus to $83 \%$ in P. caeruleus), but that they also consume benthic algae and vagile benthic invertebrates in variable proportions according to each species (Fig. 1). For example, vagile invertebrates (essentially harpacticoid copepods) represent $38 \%$ of the items found in $D$. aruanus stomachs, and benthic filamentous algae constitute $28 \%$ of $C$. dimidiata stomach contents. Finally, the cluster III groups species which consume mainly benthic algae ( $>50 \%$ of the items in their stomach contents): Plectroglyphidodon lacrymatus, Amphiprion akallopisos, Pomacentrus baenschi, Pomacentrus trilineatus and Chrysiptera unimaculata. This last species even showed more than $90 \%$ of benthic algae in its stomach contents. Within cluster III, P. baenschi was the species that had the most varied stomach contents: zooplankton (22\%), benthic algae $(53 \%)$, sessile invertebrates $(19 \%)$ and vagile invertebrates $(4 \%)$.

Stomach contents revealed no size-related diet variations in Am. akallopisos, A. vaigiensis, D. trimaculatus and $P l$ l lacrymatus (in these four species, linear regressions of each prey category versus fish size were not significant; $P>0.05)$.

Stable isotope analysis. All of the food sources had lower $\delta^{15} \mathrm{~N}$ values than the fish species (Fig. 2). Isotopic values in algae (including turf algae) ranged from -17.5 to $-8.9 \%$ for $\delta^{13} \mathrm{C}$ and from 2.0 to $6.1 \%$ for $\delta^{15} \mathrm{~N}$. Zooplankton had lower $\delta^{13} \mathrm{C}$ and higher $\delta^{15} \mathrm{~N}$ than both algae and zoobenthos.

There were highly significant differences between the delta values of the 13 pomacentrid species (one-way ANOVA: $\delta^{13} \mathrm{C}, \quad F_{(12,121)}=146.6, \quad P<0.0001 ; \quad \delta^{15} \mathrm{~N}$, $\left.F_{(12,121)}=53.65, P<0.0001\right)$. The three species clusters could be distinguished according to their mean $\delta^{13} \mathrm{C}$ values (Figs. 2, 3). The first group (A), which included Ch. unimaculata, Pl. lacrymatus and Am. akallopisos, showed the least negative $\delta^{13} \mathrm{C}$ values. Each Abudefduf species, the two Chromis species, D. trimaculatus and P. caeruleus had the most negative $\delta^{13} \mathrm{C}$ values and comprised a second assemblage (C). Pomacentrus trilineatus, P. baenschi and $D$. aruanus formed an intermediate cluster (B) along the $\delta^{13} \mathrm{C}$ axis between the first two groups. Among all species, $P$. trilineatus, Am. akallopisos and D. trimaculatus had the greatest variation in $\delta^{13} \mathrm{C}$ values. This $\delta^{13} \mathrm{C}$ variation is significantly correlated with the SL only in Am. akallopisos $\left(r^{2}=0.67 ; P<0.01\right)$, where the small specimens showed lower $\delta^{13} \mathrm{C}$ values than the largest. Dascyllus trimaculatus and Ch. unimaculata, respectively, showed the most positive and the most negative $\delta^{15} \mathrm{~N}$ values. However, even when significant differences existed between the mean values of $\delta^{15} \mathrm{~N}$ of some species, none of the clusters could be easily distinguished along this axis using this parameter.

\section{Discussion}

Stable isotopic analyses show that the 13 species can be divided into three main feeding guilds according their 
Fig. 2 Average $( \pm \mathrm{SD}) \delta^{15} \mathrm{~N}$ and $\delta^{13} \mathrm{C}$ values of the 13 pomacentrid species and of food items collected from the coral reef. Isotopic signatures of each benthic algae species are summarized in one mean and a SD that reflects their disparity. For abbreviations of the species, see Table 1. The groups A, B and $\mathrm{C}$ of fishes are respectively the benthic feeders/foragers, the intermediate group and the pelagic feeders (see the text and Fig. 3). Pomacentrid species belonging to the groups $\mathrm{A}, \mathrm{B}$ or $\mathrm{C}$ and the potential primary food sources (zooplankton, zoobenthos and algae) are represented by different icons. POM is the particulate organic matter

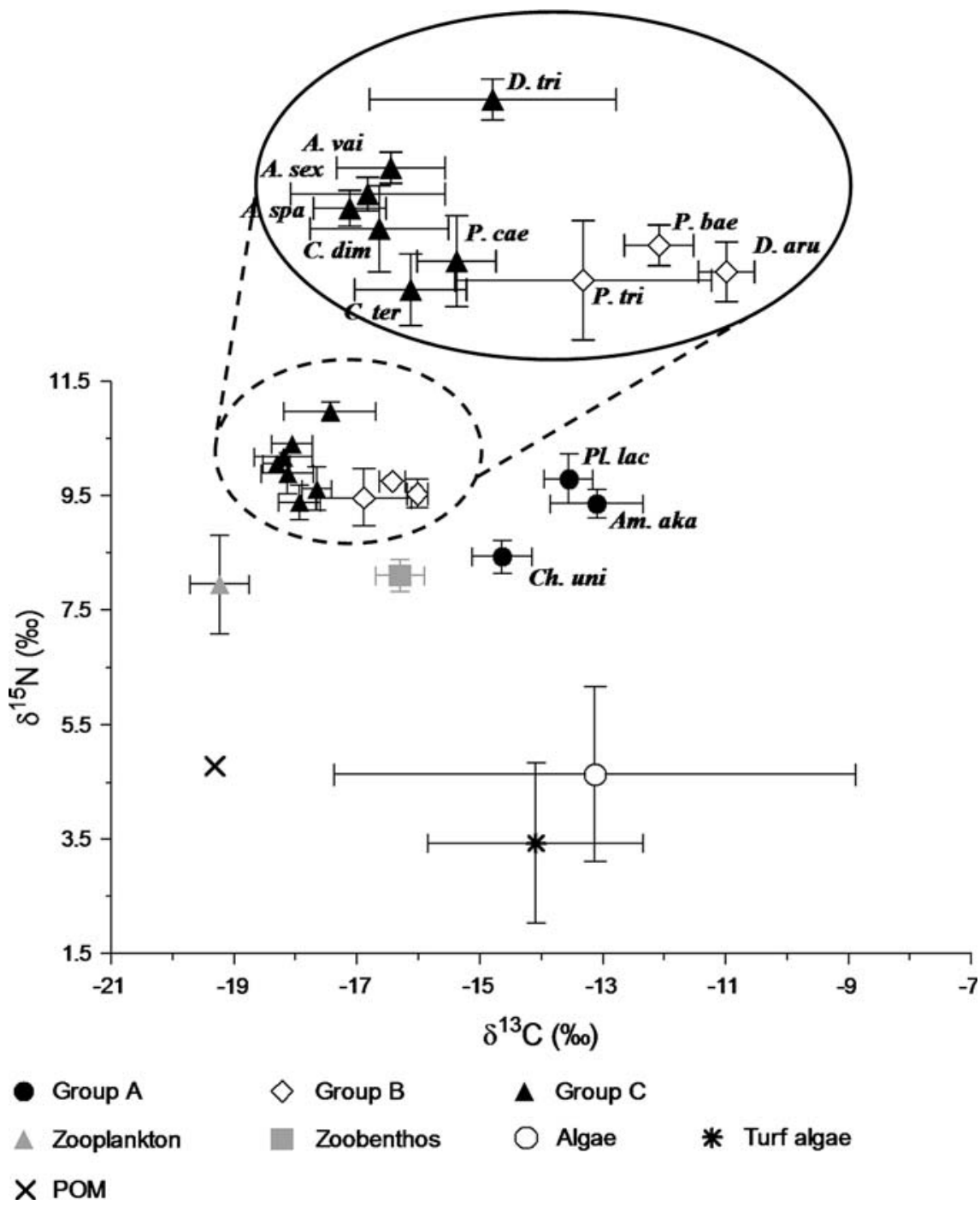

foraging strategies: benthic feeders/foragers (group A), pelagic feeders (group C) and an intermediate group (group B), feeding on both pelagic and benthic prey (Figs. 2, 3). This separation can be made along the $\delta^{13} \mathrm{C}$ axis, which represents a continuum of food sources from plankton (the most negative values) to zoobenthos and algae (the least negative values) (Bootsma et al. 1996). Pelagic feeders (Abudefduf species, Chromis species, D. trimaculatus and $P$. caeruleus) and benthic feeders (Ch. unimaculata, Pl. lacrymatus and $\mathrm{Am}$. akallopisos) had $\delta^{13} \mathrm{C}$ values that matched the isotopic signatures of, respectively, plankton and benthic prey. Pomacentrus trilineatus, P. baenschi and D. aruanus (Fig. 3) form an intermediate group in which prey could come from benthic and pelagic food webs. Generally speaking, enrichment in ${ }^{15} \mathrm{~N}$ relative to assimilated food is expected between two trophic levels (DeNiro and Epstein 1981). In this study, the $\delta^{15} \mathrm{~N}$ values of the fishes are higher than their potential food sources. Nevertheless, $\delta^{15} \mathrm{~N}$ does not allow us to discriminate between different trophic niches. Dascyllus trimaculatus displays the highest $\delta^{15} \mathrm{~N}$ values but also has a large size, and so probably occupies a higher trophic position than other pomacentrids.

Stomach content analysis provides more detail (e.g., the kind of prey generally selected) about the diet, revealing feeding preferences and some niche partitioning not shown by stable isotopes. For example, stomach contents revealed that planktonic copepods were the dominant prey of pelagic feeders (group $\mathrm{C}+D$. aruanus), as they are for the majority of diurnal planktivore fishes of coral reefs (Hobson and Chess 1978). In this group, Abudefduf sparoides, A. sexfasciatus, A. vaigiensis and C. ternatensis can be considered exclusively zooplanktivorous species (Fig. 1). Dascyllus aruanus is a carnivorous species that eats both zooplankton and vagile benthic invertebrates, explaining the intermediate position given by the stable isotope analysis. Pomacentrus caeruleus, C. dimidiata and D. trimaculatus feed mainly on zooplankton (group C), but 


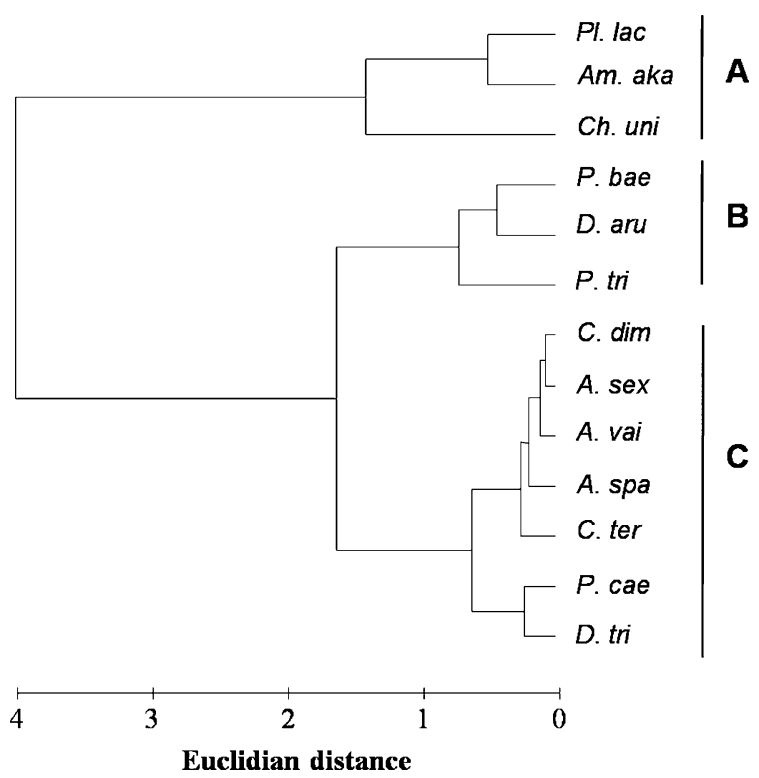

Fig. 3 Dendrogram obtained from mean $\delta^{13} \mathrm{C}$ values for each pomacentrid species. The groups A, B and C of fishes are respectively the benthic feeders/foragers, the intermediate group and the pelagic feeders. Abbreviations of the species are given in Table 1

their diets occasionally include other selected food sources from the benthic compartment: algae and/or benthic invertebrates. The stomach contents of the benthic feeders (group A) are composed of variable proportions of filamentous algae. Plectroglyphidodon lacrymatus and Am. akallopisos could be considered to be omnivorous, feeding mainly on benthic algae, while Chrysiptera unimaculata appears to be almost exclusively an algivore.

Although $P$. baenschi and P. trilineatus belong to the same feeding group (group B), stable isotope analysis suggests that their trophic niche widths are different (Bearhop et al. 2004). Pomacentrus baenschi may be a true omnivore (Fig. 1), and the very low variations in $\delta^{13} \mathrm{C}$ in its muscle tissue may suggest that the prey components in its diet are very consistent over time. On the other hand, stomach content analysis shows that filamentous algae essentially compose the diet of $P$. trilineatus, which does not directly correlate with its stable isotope signatures. This algal domination in the stomach contents could be accidental; diet-switching over time is suggested by the variation in the $\delta^{13} \mathrm{C}$ values. This intrapopulation variability in prey choice could be related to factors like predation, competition and/or prey abundance.

The variation in $\delta^{13} \mathrm{C}$ signatures in Am. akallopisos is size-related, and it could reflect ontogenetic changes in food preference (i.e., anemone tissue, which is only slowly digested; Mariscal 1970; Allen 1991) or ontogenetic changes in behavior (i.e., dead egg removal in males; Allen 1991) which were not revealed by stomach content analysis, or it could be related to ontogenetic variability in

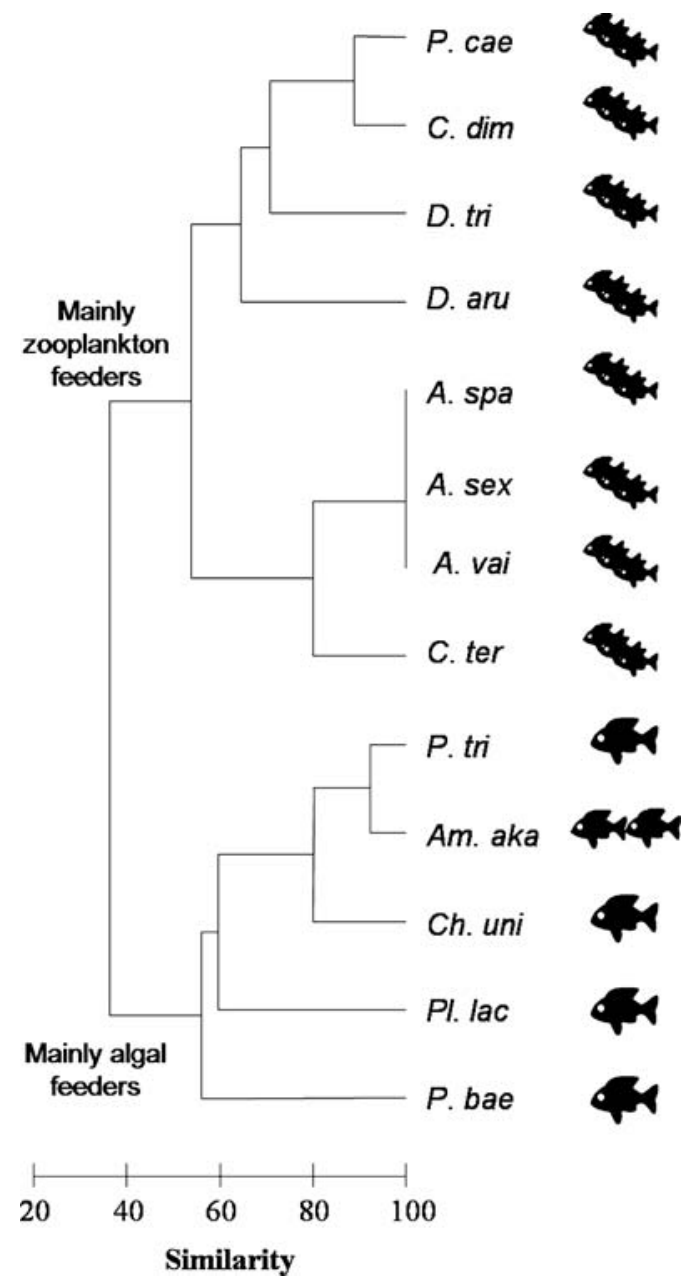

Fig. 4 Dendrogram of the 13 pomacentrid species, constructed based on the similarity matrix of trophic niches. Solitary species, species living in pairs or in groups are depicted by icons showing one, two or three fish(es), respectively. For abbreviations of the species, see Table 1

diet-tissue fractionation and/or physiology (Bearhop et al. 2004).

Diversity of feeding habits in damselfishes. In the coral reef ecosystem of Toliara, the Pomacentridae belong to three feeding guilds which exploit different ecosystem compartments: pelagic feeders, benthic feeders and a third group which feeds on both pelagic and benthic biota. The first guild includes zooplanktivore species. In the second and third groups, we found species that feed on small vagile animals, sessile animals (to a lesser extent) and/or algae. This supports the general trends observed in other pomacentrids from different geographical areas (Emery 1973; Allen 1991; Kuo and Shao 1991). Only two species are known to be coral polyp feeders (Allen 1991; Kuo and Shao 1991): Cheiloprion labiatus and Plectroglyphidodon johnstonianus. The dietary diversity among sympatric damselfishes is relatively low in comparison with the 
diverse trophic niches of Labridae (e.g., macro-mollusc, Brachyura, fish, coral, Foraminifera, gnathiid feeders) (Wainwright and Bellwood 2002). This might be because zooplankton, small benthic prey and filamentous algae are not limiting factors in coral reefs, thus facilitating species coexistence (Anderson et al. 1981). The diversity of damselfishes may be mainly related to behavior and habitat choice (Waldner and Robertson 1980; Ormond et al. 1996). The studied species that feed on algae are solitary (except in the case of pairs of Am. akallopisos that live in anemones) and live close to the reef bottom, in shelters among living or dead coral, or rubble areas in shallow water (Fig. 4) (Allen 1991; B.F., personal observation). Pomacentrus baenschi appears to have different shelters covering a relatively large area (approximately $3 \mathrm{~m}^{2}$, B.F., personal observation), but in the other species, an individual is associated with just one shelter. Species feeding mainly on small pelagic prey are generally found in aggregations (schooling species) (Emery 1973). Exclusive zooplankton feeders, such as the three species of Abudefduf and $C$. ternatensis, remain just above the reef, in the water column (Allen 1991; B.F., personal observation). The adults of D. trimaculatus occur in small to large aggregations, and their juveniles are often commensal with large sea anemones or small coral heads (Allen 1991). Dascyllus aruanus form social groups that live in association with branched corals (Allen 1991). Chromis dimidiata schools just over the reef, and $P$. caeruleus swims near the substrate and does not usually move away from the reef (B.F., personal observation). All of these observations agree with Emery's (1973) results on other damselfish species in the Florida Keys and reveal that diet, habitat and behavior are strongly correlated in damselfishes.

Acknowledgments The authors would like to thank J. M. Ouin and his Aqua-Lab team, Prosper and the Institut Halieutique et des Sciences Marines of the Toliara University for helping to collect the fishes and for providing hospitality and laboratory facilities. We are grateful to M. Harmelin-Vivien and to P. Dauby for their assistance in stomach content analysis. The comments and suggestions of the Editor Y. Sakai, Prof. R. Galzin and an anonymous reviewer were also very helpful when revising the manuscript. The authors thank P. Smith for her linguistic assistance. E.P. is a Research Associate of the Belgian National Fund for Scientific Research (FRS-FNRS). This work was funded by FRS-FNRS (FRFC contract no. 2.4.583.05). This paper is MARE paper number 141.

\section{References}

Allen GR (1991) Damselfishes of the world. Mergus, Melle, Germany Anderson GRV, Ehrlich AH, Roughgarden JD, Russel BC, Talbot FH (1981) The community structure of coral reef fishes. Am Nat 117:476-495

Barel CDN (1983) Towards a constructional morphology of cichlid fishes (Teleostei, Perciformes). Neth J Zool 33:357-424
Bearhop S, Adams CE, Waldron S, Fuller RA, Macleod H (2004) Determining trophic niche width: a novel approach using stable isotope analysis. J Anim Ecol 73:1007-1012

Bootsma HA, Hecky RE, Hesslein RH, Turner GF (1996) Food partitioning among Lake Malawi nearshore fishes as revealed by stable isotope analysis. Ecology 77:1286-1290

Ceccarelli DM (2007) Modification of benthic communities by territorial damselfish: a multi-species comparison. Coral Reefs 26:853-866

Coates D (1980) Prey-size intake in humbug damselfish, Dascyllus aruanus (Pisces, Pomacentridae) living within social groups. J Anim Ecol 49:335-340

Cocheret de la Morinière E, Pollux BJA, Nagelkerken I, Hemminga MA, Huiskes AHL, Van der Velde G (2003) Ontogenetic dietary changes of coral reef fishes in the mangrove-seagrass-reef continuum: stable isotopes and gut-content analysis. Mar Ecol Prog Ser 246:279-289

Colwell RK, Fuentes ER (1975) Experimental studies of the niche. Annu Rev Ecol Syst 6:281-310

DeNiro MJ, Epstein S (1981) Influence of diet on the distribution of nitrogen isotopes in animals. Geochim Cosmochim Acta 45:341-351

Emery AR (1973) Comparative ecology and functional osteology of fourteen species of damselfish (Pisces: Pomacentridae) at Alligator Reef, Florida Keys. Bull Mar Sci 23:649-770

Ferry-Graham LA, Wainwright PC, Bellwood DR (2001) Prey capture in long-jawed butterflyfishes (Chaetodontidae): the functional basis of novel feeding habits. J Exp Mar Biol Ecol 256:167-184

Gobler CJ, Thibault DB, Davis TW, Curran PB, Peterson BJ, Liddle LB (2006) Algal assemblages associated with Stegastes sp. Territories on Indo-Pacific coral reefs: characterization of diversity and controls on growth. J Exp Mar Biol Ecol 336:135-145

Hata H, Kato M (2002) Weeding by the herbivorous damselfish Stegastes nigricans in nearly monocultural algae farms. Mar Ecol Prog Ser 237:227-231

Hobson ES, Chess JR (1978) Trophic relationships among fishes and plankton in the lagoon at Enewetak atoll, Marshall Islands. Fish Bull 76:133-153

Hyslop EJ (1980) Stomach contents analysis-a review of methods and their application. J Fish Biol 17:411-429

Kuo SR, Shao KT (1991) Feeding habits of damselfish (Pomacentridae) from the southern part of Taiwan. J Fish Soc Taiwan 18:165-176

Lecchini D, Galzin R (2005) Spatial repartition and ontogenetic shifts in habitat use by coral reef fishes (Moorea, French Polynesia). Mar Biol 147:47-58

Leis JM, Carson-Ewart BM (2002) In situ settlement behavior of damselfish (Pomacentridae) larvae. J Fish Biol 61:325-346

Ormond RFG, Roberts JM, Jan RQ (1996) Behavioural differences in microhabitat use by damselfishes (Pomacentridae): implications for reef fish biodiversity. J Exp Mar Biol Ecol 202:85-95

Mann DA, Sancho G (2007) Feeding ecology of the domino damselfish, Dascyllus albisella. Copeia 3:566-576

Mariscal RN (1970) The nature of the symbiosis between Indo-Pacific anemone fishes and sea anemones. Mar Biol 6:58-65

Motta PJ (1988) Functional morphology of the feeding apparatus of ten species of Pacific butterflyfishes (Perciformes, Chaetodontidae): an ecomorphological approach. Environ Biol Fish 22:3967

Nelson JS (2006) Fishes of the world. Wiley, Hoboken, NJ

Noda M, Kawabata K, Gushima K, Kakuda S (1992) Importance of zooplankton patches in foraging ecology of the planktivorous reef fish Chromis chrysurus (Pomaentridae) at Kuchinoerabu Island, Japan. Mar Ecol Prog Ser 87:251-263 
Parmentier E, Das K (2004) Commensal vs. parasitic relationship between Carapini fish and their hosts: some further insight through $\delta^{13} \mathrm{C}$ and $\delta^{15} \mathrm{~N}$ measurements. J Exp Mar Biol Ecol 310:47-58

Peterson BJ, Fry B (1987) Stable isotopes in ecosystem studies. Annu Rev Ecol Syst 18:293-320

Pinnegar JK, Polunin NVC (1999) Differential fractionation of $\delta^{13} \mathrm{C}$ and $\delta^{15} \mathrm{~N}$ among fish tissues: implications for the study of trophic interactions. Funct Ecol 13:225-231

Pratchett MS (2005) Dietary overlap among coral-feeding butterflyfishes (Chaetodontidae) at Lizard Island, northern Great Barrier Reef. Mar Biol 148:373-382

Silvertown J (2004) Plant coexistence and the niche. Trends Ecol Evol 19:605-611

Streelman JT, Danley PD (2003) The stages of vertebrate evolutionary radiation. Trends Ecol Evol 18:126-131

Wainwright PC (1988) Morphology and ecology: functional basis of feeding constraints in caribbean labrid fishes. Ecology 69:635645
Wainwright PC, Bellwood DR (2002) Ecomorphology of feeding in coral reef fishes. In: Sale PF (ed) Coral reef fishes: dynamics and diversity in a complex ecosystem. Academic, San Diego, CA, pp 33-57

Wainwright PC, Bellwood DR, Westneat MW, Grubich JR, Hoey AS (2004) A functional morphospace for the skull of labrid fishes: patterns of diversity in a complex biomechanical system. Biol J Linn Soc 82:1-25

Waldner RE, Robertson DR (1980) Patterns of habitat partitioning by eight species of territorial caribbean damselfishes (Pisces: Pomacentridae). Bull Mar Sci 30:171-186

Wellington GM, Victor BC (1989) Planktonic larval duration of one hundred species of Pacific and Atlantic damselfishes (Pomacentridae). Mar Biol 101:557-567 